\title{
Pronunciation for the Arab Learners of EFL: Planning for Better Outcomes
}

\author{
Arif Ahmed Mohammed Hassan Al-Ahdal ${ }^{1}$, Abdulghani Ali Al-Hattami ${ }^{2}$, \\ Salmeen Abdulrahman Abdullah Al-Awaid ${ }^{3} \&$ Nisreen Juma'a Hamed Al-Mashaqba ${ }^{1}$ \\ ${ }^{1}$ Qassim University, KSA \\ ${ }^{2}$ University of Bahrain, Bahrain \\ ${ }^{3}$ Jazan University, KSA \\ Correspondence: Arif Ahmed Mohammed Hassan Al-Ahdal, Qassim University, KSA. E-mail: \\ arif_al_ahdal@yahoo.com
}

Received: July 23, 2015 Accepted: September 8, 2015 Online Published: September 11, 2015

doi:10.5539/elt.v8n10p100 URL: http://dx.doi.org/10.5539/elt.v8n10p100

\begin{abstract}
Arabic and English belong to two different linguistic families: resultantly, some Arabic speaking learners of English in both SL and FL situations have a major obstacle to overcome to be intelligible to other users, especially in the international context. Of the various skills one needs to acquire to become 'proficient' in a language Pronunciation is perhaps the one most relevant to real time usage. However, this is ironically also an area of training that is relegated to the 'not so important' category in the EFL classroom in Saudi Arabia as a result of which learner aspirations are not fulfilled in learning English. The current study empirically evaluates the present pronunciation proficiency of Saudi learners at Qassim University, KSA and checks the outcomes of a pronunciation intervention programme. Its aim is to document the specific linguistic elements of difference using empirical means. It further aims to suggest methods to bring the Arab learners' pronunciation closer to an optimum level of universal communication as well as arrive at generalizations to enable policy changes commensurate with learner aspirations.
\end{abstract}

Keywords: pronunciation, approaches, supra-segmentals, tone, rhythm, intonation, near native pronunciation

\section{Introduction}

The factors that bring pronunciation to the fore of language training are central to effective communication: Mutual intelligibility and communicability. In EFL situations, work force the world over today is put under high English demand not only in their home nation but also in the country where they may choose to work. Technocrats, academicians, scientists, business people need proficiency in written and spoken English in practically all careers: trade and commerce, scientific and technological fields, research, banking; the list is endless. That English is the lingua franca of all means of livelihood is a reality. English is the world's most dominant language of scholarship and research forworkers (college and university professors) and consumers (students) in these fields. Conferences and scholarly and research papers alike resort to English for the simple reason of world wide readability.Students who want to enrol for degree and other programmes in English speaking universities need high written and spoken English quotient. Given the extent of immigration to English speaking countries, poor pronunciation has the potential for mis-communication and consequent language prejudice. Only those NNSs who are proficient in writing and speaking skills, along with a fair command of the other two skills, can survive to fulfil their career goals. Consequently, EFL teachers have to focus on communicative skills in general and speech intelligibility in particular, of their learners. In the population that we have chosen for this study, pronunciation is undoubtedly the biggest casualty.In fact so neglected is this area of research that it lies at the very margins of applied linguistics. The result of this is that teachers are often left to rely on their own 'feeling' with little direction in the pronunciation classroom. Although some instructors can successfully assist their students under these conditions, many others are reluctant to teach pronunciation. These very factors encouraged us to undertake the current study to help the teachers and students in terms of setting 
learning goals, identifying suitable pedagogical priorities for the classroom, and determining the most effective approaches to teaching pronunciation.

The curriculum of Qassim University has a mere 3 credit course on pronunciation component. Notwithstanding this, in the face of lack of training, whatever little pronunciation the teachers integrate into classroom teaching is based on their intuition. However, ignoring or failing to fulfill students' pronunciation needs translates to abrogation of professional responsibility by the teachers. In programmes for adult EFL learners in particular, it is a given factor that students' educational, occupational, and personal/social language needs, including reasonably intelligible pronunciation, be served with instruction that will make them communicatively empowered-effective language users that will help them to succeed. Moreover, with an increasing focus on communication, oral comprehensibility has gained place, making it critical to provide instruction that enables students to become, not "perfect pronouncers" of English but, communicative, intelligible and confident users of spoken English for whatever purposes they need.

\section{Approaches to the teaching of Pronunciation}

In Pronunciation Teaching- History and Scope, (1996), Celce Murcia et al. summarised the two main approaches to the teaching of Pronunciation:

\subsection{An intuitive-imitative Approach}

(1) depends on the learner's ability to listen to and imitate the rhythms and sounds of the target language without the intervention of any explicit information;

(2) presupposes the availability, validity, and reliability of good models to listen to.

\subsection{An Analytic-linguistic Approach}

(1) utilizes information and tools such as a phonetic alphabet, articulatory descriptions, charts of the vocal apparatus, contrastive information, and other aids to supplement listening, imitation, and production.

(2) explicitly informs the learner of and focuses attention on the sounds and rhythms of the target language.

(3) was developed to complement rather than to replace the intuitiveimitative approach, which was typically retained as the practice phase used in tandem with the phonetic information.

It may be worthwhile, however, to point out as chronicled by Richards (1995) that language reformers from as early as the late nineteenth century believed among other things that

(1) the spoken language is primary;

(2) the findings of phonetics should be applied to teaching and to teacher training;

(3) learners should hear the language first;

\section{Literature Review}

Pronunciation studies were few and insufficient till the beginning of the 80s. As quoted by Joan Morley in The Pronunciation Component in Teaching English to Speakers of Other Languages (1991), Prator (1971) examined issues relating to phonetics versus phonemics in pronunciation teaching; Allen (1971) wrote on intonation, providing practice suggestions that continue to be cited today; Bowen (1972) focused on contextualizing practice in the classroom, with a classic format that is still recommended, for example, by Celce-Murcia and Goodwin (1991) who refer to it as "Bowen's Technique"; Kriedler (1972), W. Dickerson (1975), and Dickerson and Finney (1978) stressed the importance of the spelling/pronunciation link for learners; Morley (1975) emphasized the need for learner- involvement and speech self-monitoring; Robinett (1975) suggested ways to present information in a manner that appeals to students' cognitive involvement; Stevick (1975) turned attention to a view of the learner's feelings and the importance of the affective dimension in learning; L. Dickerson (1975) and W. Dickerson (1976) looked at aspects of variability in L2 pronunciation performance; Cathcart and Olsen (1976) reported on teachers' and students' preferences for correction; Parrish (1977) and Stevick (1978) presented viewpoints on a practical philosophy of pronunciation with attention to issues involving linguistic, affective, social, and methodological considerations; G. Brown $(1977,1978)$ underscored the importance of focusing listening attention on prosodic patterning; Beebe (1978) provided some sociolinguistic perspectives on "teaching pronunciation, why we should be"; Smith and Rafiqzad (1979) investigated mutual intelligibility among speakers from different cultures. 
With a marked change in perspectives on language learning and language teaching, the ideal language classroom today has seen a gradual shift from an emphasis on teaching and a teaching-centred approach to an emphasis on learning and a learning-centred classroom, with special attention to the individual learner as well as the group of learners. At the same time, as pointed out by Canale and Swain (1980) there has been a shift from a narrow focus on linguistic competencies to a broader focus on communicative competencies, within which linguistic competencies (i.e., grammar, pronunciation, etc.) remain an essential component albeit only one of several critical competencies.

The decades beginning 1980s saw the question of pronunciation instruction being studied extensively.James Enile Flege (1981) worked on the phonological basis of foreign accent. Denis R. Preston (1981) studied the ethnogarphy of TESOL; In a very interesting study Alice Myers Roy (1984) worked on teaching non native speakes and speakers of non standard English together; Orlando R. Kelm (1985) studied acoustically the difference in the speech of native and non native speakers of Spanish; Garry Molholt (1990) worked on a spectrographic analysis of second language phonology. His subjects were Chinese users of American English. Joan Morley (1991) studied the pronunciation component in teaching English to speakers of other languages. Karen Earline Schairer (1992) native speaker reaction to non native speech; Vivian Cook (1999) studied the appropriateness of the models in language use set by the native users ina mixed classroom; Marnie Reed's research of year 2000 examines the occurrence of hesitation in spontaneous speech of native and non native speakers; Roy C. Major et al (2002) examined the effects of non native accents on listening comprehension and stuied their implications for ESL assessment; Mary Grantham O'Brien (2004) enumerated upon the significance of pronunciation in an article aptly titles 'Pronunciation Matters';John M. Levis (2005) studied the changing contexts and shifting paradigms in pronunciation teaching; Nico C. Sifakis and Areti Maria Sougari (2005) studied the teachers' viewpoint on pronunciation specific issues and the possible links between pronunciation teaching, English as an international language, and the socio cultural identity of non native speakers of English. The 'native speaker myth' was studied by Paula Golombek and Stefanie Rehn Jordan (2005) studied the aspects of intelligibility and identity; A variety of English accents were the subject of the study carried out by Julie Scales et al (2006) where they studied the language learners' perception of accent; Deyuan He and Qunying Zhang (2010) worked on native speaker norms and China English, from the perspective of learners and teachers in China.

In English Pronunciation Teaching: Four Case Studies from Finland (2012) Elina Tergujeff has this to say: "Positive effects of pronunciation instruction have been reported in numerous studies. These studies suggest that instruction at both segmental and suprasegmental levels can result in improved pronunciation skills, and that teaching methods such as discrimination practice (e.g. Neufeld, 1977, 1978 quoted in Neufeld \& Schneiderman 1980; Derwing et al., 1998), concrete rules, giving immediate feedback (e.g. Elliott, 1995, 1997), and imitation (e.g. Macdonald, Yule, \& Powers, 1994) have had positive effects on the learning of pronunciation. In a comparison of narrow/segmental and broad/suprasegmental approaches, Derwing et al. (1998) conclude that the suprasegmental approach is more effective in terms of comprehensibility, accentedness and fluency."

Further that "Observing 32 EFL lessons revealed a range of ten different types of pronunciation teaching methods, including traditional imitation tasks, teacher corrections, teachers pointing out pronunciation issues, reading aloud, use of phonemic script and rhymes, presenting rules, dictation/spelling, sound discrimination, and tactile reinforcement."

"Overall, the pronunciation teaching practices can be characterised as being teacher-led to a great extent. This does not correlate well with the principles of communicative language teaching (CLT), which usually aims at promoting learner autonomy and being learner-centred. In many instances the teacher interfered with and corrected a pupil's pronunciation, or gave them information about the pronunciation of a word. Communicative pronunciation tasks were hardly used in the observed lessons. Even though we are living the era of CLT, in fact, CLT and pronunciation teaching is a complicated combination, as stated by Seidlhofer (2001): CLT directs the learners" attention to communication and away from form, but a certain formal aspect, such as pronunciation, can be difficult to learn unless one pays attention to it. This is also demonstrated in Elliott $(1995,1997) . "$

Since the current study also has as its focus the suprasegmental features of pronunciation among the EFL learners of Saudi Arabia, the findings of Elina Tergujeffare especially relevant.

\section{Statement of the Problem}

In a study in 1980, Hinofotis and Bailey reported that out of 12 subcategories of problems, pronunciation was 
ranked first by undergraduate student raters as well as by TESL (Teaching fo English as Second Language) and TA training raters. Beebe (1978) observed, in an era of focus on meaningful communication, it is important for ESL professionals to take note that "pronunciation-like grammar, syntax, and discourse organization-communicates [italics added] ... the very act of pronouncing, not just the words we transmit, are an essential part of what we communicate about ourselves as people" (p. 121). She reported that NSs often label NNS pronunciation errors derisively, as sounding comical, cute, incompetent, not serious, childish, etc. This study is our attempt to suggest certain practical pedagogical modifications to enable the EFL learners in Saudi Arabia to communicate intelligibly not only to other NNSs (Non Native Speakers) but also NSs (Native Speakers) of English.

\section{Method}

The present study focuses on English pronunciation of Saudi students from the Qassim University. We chose two groups of EFL students ( $\mathrm{n}=10$ each) who had spent the last one year at the university but were taught English by native speakers. All the subjects chosen belonged to the same class. In the pre intervention stage, we selected a 1000 word translated version of Alf Laylah in English. Each of the subjects was made to read aloud the story aloud while their responses were recorded. Native speakers of English who were our colleagues later rated these samples. The language background of the subjects was not revealed to them.

a) What is the focus of group 1 (mentored in English pronunciation/speechbyme): is it individual sounds or the overall feel of the speech as governed by prosodic features?

b) What is the effect of language exposure, ie. how did the two learner groups 1 and 2 score on global pronunciation ratings given by native speakers of English?

c) What are the factors that promote native-like global pronunciation?

This was followed by a two weeks' course running into a total of twelve hours that we undertook for group 2 who were the experimental group. During this course, we exposed them to drills in reading aloud in English. Our focus was on the speed, pauses, tone and other prosodic features of speaking/reading. The responses of both the groups were again recorded while they read aloud the earlier story again. Following this, the speech samples were rated by NSs and results compared to the previous ones.

\section{Findings}

At the end of the pilot study, we had arrived at the conclusion that native speakers focused more on prosodic elements viz. stress, rhythm, intonation, speech rate and sentence melody when asked to rate speech samples on a scale of 1-5 where 1 stands for 'poor speech skills' and 5 for 'near native speech skills'. Accordingly we used the same scale both the times the NSs were asked to rate the subjects' speech samples and their ratings recorded. We named the two groups of subjects $A$ and $B$ to denote the pre intervention results and $C$ and $D$ to denote the post intervention results. It may be noted, however, that $A$ and $C$ comprise the same set of subjects ie the control group whereas, B and D likewise are the same set of experimental subjects, albeit B is the pre intervention outcome and $\mathrm{D}$ is the post intervention outcome.

The correlation between the sum totals of the five parameters of each subject is calculated for Groups A and B (the two groups of subjects before intervention). This is a parameter which shows the efficacy of the five parameters that we have used with two groups of subjects. The results show very interesting trends. A and B which are random groups of presumably similar linguistic competence, show a minor positive correlation of 0.26428556 and groups A and C show an extremely high correlation of 0.8253401 . Translated to simple language, this means that it is proven statistically that groups $\mathrm{A}$ and $\mathrm{C}$ are the same set of subjects.

Similarly, B and D (which represent the same group of subjects but post intervention) show a very high correlation whose performance increased proportionally across board. This is how a high correlation of 0.80017335 can be explained. Once trained in prosodics, the group's performance showed significant improvement in terms of ratings by NSs. This means that their speech was adjudged as having come closer to what NSs would produce.

Applying another instrument, the average values of the sum totals of individual participants of Groups A, B, C, $\mathrm{D}$ are $4.1,4.3,4.0$ and 9.6 respectively. As we can see, the highest average is logged by group $\mathrm{D}$ which was exposed to extra hours of pronunciation training. Again, A, B, C denote ratings by NSs before training was provided to the subjects where $\mathrm{A}$ and $\mathrm{C}$ are the same set of learners. However post intervention (totalling to 
twelve hours of training in prosodics) D shows that the average scores improved drastically from 4.3 to 9.6 . This is an increase of 54.67 points that translates to a $132.26 \%$ in performance! Based upon these encouraging results, we present here our recommendations.

\section{Recommendations}

Our study clearly revealed that classroom practice in KSA does not focus enough on pronunciation/speech practice with prosodics which is in reality the only aspect of speech that is the most important for our students' success when they communicate with native speakers of English. Teachers find pronunciation instruction difficult, most often due to a lack of training and a certain level of doubt with the technical nature of the subject matter. However, during an informal interaction when we spoke to our undergraduate students at the University, they said that a native-like accent in English is even more important to them than correct grammar. Isn't it ironic then that our "communicative" language classrooms are not preparing our students to communicate?

Here are some practical implications for classroom teachers that may be drawn from the results of this study.

1). Classroom pronunciation training should begin early.

2). Phonics or sound-symbol correspondence should be a major component in the training.

3). Prosodic aspects, rhythm, tone, intonation and stress should replace the flat reading resorted to by the learners and teachers.

4). More opportunities for applying the prosodics should be created in the syllabus, for instance, by incorporating role play, poem recitation, skits and voice over.

5). While tackling grammar, discourse or lexis in the classroom, prosodics should be integrated into the lesson.

6). In the early stage of EFL education, assessment based on degree of change should cover intonation as one of the components.

7). The classroom environment should be supportive and encouraging, calling error correction as 'modification' to enable even the most 'unintelligible' of students to get over their shyness and embarrassment.

8). Spelling oriented pronunciation practice can be very effective to help the learners develop the fast speech phenomena of authentic oral production. At the early stages of EFL instruction, learners should be encouraged to recognise words at sight and be able to speak them.

9. Finally, the Three Modes of Practice proposed by Joan Morley in The Pronunciation Component in Teaching English to Speakers of Other Langaugescan be implemented. Its components are:

(i) Imitative Speaking Practice: This kind of practice should be used only as necessary and, in fact, may be introduced as a short-term component within a rehearsed or extemporaneous practice context, especially with advanced or intermediate students. The purpose of the practice is to focus on controlled production of selected pronunciation/speech features.

(ii) Rehearsed Speaking Practice: This kind of practice can be used in a variety of ways as a practice mode in its own right as well as an interim step between imitative and extemporaneous practice. The purpose of the practice is to work toward stabilization of modified pronunciation/speech pat- terns (i.e., discrete-point features, global features, etc.) so that the learner can manipulate them easily at will. Practice can include oral reading scripts of a wide variety, either teacher-selected or self- selected or composed by teachers and/or students (e.g., simulated radio or TV broadcast scripts of all kinds; excerpts from famous speeches, plays, narrative poems, novels, role-play skits and playlets, etc.; preplanned (relatively short) oral presentations of a wide variety, with topics self-selected); in-class dress rehearsal and final performance with audio- and/or videotaping (and feedback critique sessions either immediately or later); out-of-class self-study rehearsals or paired/small-group rehearsal study sessions with audio- and/or videotaping; one-on-one individual speech work-out study sessions with the speaking teacher (i.e., speech coach).

(iii) Extemporaneous Speech Practice: This kind of practice can be used with a wide variety of speaking tasks and activities, and is for the purpose of working toward integration of modified speech patterns into naturally occurring creative speech in both partially planned and unplanned talks (monologues). It can include small-group panel discussion presentations, both formal and informal (preplanned outside of class or planned relatively spontaneously during class time in small- group work sessions and presented immediately); audience- interaction follow-up dialogue sessions in a question-and-answer format; in-class presentations with audio- and/or 
videotaping; out- of-class self-study rehearsals individually, in pairs, or in small-group preparation sessions; one-on-one individual work-out speech sessions with the teacher with audio- and/or videotaping and feedback sessions.

\section{Conclusion}

Though no empirical study can be perfect, based upon the very encouraging findings of the current study we take the liberty to conclude by adding that the status of English pronunciation in the Saudi Arabian language classroom may not be the most desirable, but the possibilities of improving these are endless. Steps need to be taken at two levels: Policy making and requisite Teacher Training. At the same time we would also recommend similar studies on a larger scale (which could not be conducted, given our specific time and place constraints) in order to arrive at an even better generalization.

\section{References}

Abdul, H. F. (1982). An Analysis of Syntactic Errors in the Composition of Jordanian Secondary Students. MA Thesis, Jordan, Yarmouk University.

Ahmad, J. (2005). Pronunciation Problems among Saudi learners: A Case Study at Preparatory Year Programme. Nigran University Saudi Arabia. Language in India, 11(7), 22-36.

Ahmad, J. (2011). Pronunciation Problems among Saudi Learners: A Case Study at the Preparatory Year Program. Najran University, Saudi Arabia, 36.

Alfallaj, F. (2012). The Technical and Vocational Training Corporation. New Approach in evaluating English at the College of Technology in Buraydaha Saudi Arabia. College of Education, Mogazine, 28(2). Assuat University Press.

Al-Hattami, A. A. (2010). A Phonetic and Phonological Study of the Consonants of English and Arabic. Language in India, 10, 242-365.

Alkuli, M. (1989). Teaching English to Arab Students. King Saud University Press. Riyadh, Saudi Arabia.

Al-Shuaibi, A. (2009). A phenomenal Analysis of English Phonotactics of Syllable: Initial and Final Consonant Clusters by Yemeni Speakers of English. M. A. Dissertation. Language in India, 9, 195-328.

Al-Shuaibi, A. (2010). Phonological Analysis of English Phonotactics of Syllable Initial and Final Consonant Clusters by Yemeni Speakers of English. M.A. Dissertation.

Altaha, F. (1995). Pronunciation errors made by Saudi university students learning English: Analysis and remedy. International Review of Applied Linguistics, 109, 110-123.

Binturki, T. A. (2008). Analysis of pronunciation errors of Saudi ESL learners. MA Dissertation, Southern Illinois University, USA.

Cook, V. (1999). Going beyond the Native Speaker in Language Teaching. TESOL Quarterly, 33(2), 185-209. http://dx.doi.org/10.2307/3587717

Emad, M. Al. (2010). Phonological Analysis of English Phonotactics: A Case Study of Arab Learners of English. The Buckinghum Journal of Language and Linguistics, 3, 121-134.

Flege, J. E. (1981). The Phonological Basis of Foreign Accent: A Hypothesis. TESOL Quarterly, 15(4), 443-455. http://dx.doi.org/10.2307/3586485

Golombek, P., \& Jordan, S. R. (2005). Becoming "Black Lambs" Not "Parrots": A Poststructuralist Orientation to Intelligibility and Identity. TESOL Quarterly, 39(3), 513-533. http://dx.doi.org/10.2307/3588492

Harb, R. H. (2006). Native Speakers of Arabic and ESL Texts: Evidence for the Transfer of Written Word Identification Processes. TESOL Quarterly, 40(2), 321-339. http://dx.doi.org/10.2307/40264525

Harrison, W., Prator, C., \& Tucker, G. (1975). English Language Policy Survey of Jordan. Centre for Applied Linguistics, Arlington VA.

He, D., \& Zhang, Q. (2010). Native Speaker Norms and China English: From the Perspective of Learners and Teachers in China. TESOL Quarterly, 44(4), 769-789. http://dx.doi.org/10.5054/tq.2010.235995

Iragui, J. C. (1996). Requests and apologies: a comparison between native and non-native speakers of English. Atlantis, 18(1/2), 53-61. 
Kelm, O. R. (1987). An Acoustic Study on the Differences of Contrastive Emphasis between Native and Non-Native Spanish Speakers. Hispania, 70(3), 627-633. http://dx.doi.org/10.2307/343447

Kharma, N., \& Hajjaj, A. (1989). Errors in English among Arabic speakers: Analysis and remedy. Longman: London.

Kharma, N., \& Hajjaj, A. (2011). Errors in English among Arabic speakers: Analysis and remedy Language in India, 11(7).

Kobayashi, T. (1992). Native and Nonnative Reactions to ESL Compositions. TESOL Quarterly, 26(1), 81-112. http://dx.doi.org/10.2307/3587370

Levis, J. M. (2005). Changing Contexts and Shifting Paradigms in Pronunciation Teaching. TESOL Quarterly, 39(3), 369-377. http://dx.doi.org/10.2307/3588485

Major, R. C. (2002). The Effects of Nonnative Accents on Listening Comprehension: Implications for ESL Assessment. TESOL Quarterly, 36(2), 173-190. http://dx.doi.org/10.2307/3588329

Molholt, G. (1990). Spectrographic Analysis and Patterns in Pronunciation. Computers and the Humanities, 24(1/2), 81-92. http://dx.doi.org/10.1007/BF00115030

Morley, J. (1991). The Pronunciation Component in Teaching English to Speakers of Other Languages. TESOL Quarterly, 25(3), 481-520. http://dx.doi.org/10.2307/3586981

Murcia, C. (1996). Pronunciation Teaching History and Scope. Retrieved from Books.google.com

O'Brien, M. G. (2004). Pronunciation Matters. Die Unterrichtspraxis / Teaching German, 37(1), 1-9. http://dx.doi.org/10.1111/j.1756-1221.2004.tb00068.x

PSifakis, N. C., \& Sougari, A. (2005). Pronunciation Issues and EIL Pedagogy in the Periphery: A Survey of Greek State School Teachers' Beliefs. TESOL Quarterly, 39(3), 467-488. http://dx.doi.org/10.2307/3588490

Preston, D. R. (1981). The Ethnography of TESOL. TESOL Quarterly, 15(2), 105-116. http://dx.doi.org/10.2307/3586402

Rakas, M. S. (2008). Problematic Issues Facing Libyan Arab Learners of English. Retrieved from www.garyounis.edu/arts/magazine_art/art30/10.pdf

Rao, Z. (2002). Chinese Students' Perceptions of Communicative and Non-communicative Activities in EFL Class Room. System, 30, 85-105. http://dx.doi.org/10.1016/S0346-251X(01)00050-1

Reed, M. (2000). He Who Hesitates: Hesitation Phenomena as Quality Control in Speech Production, Obstacles in Non-Native Speech Perception. The Journal of Education, 182(3), 67-91.

Richards, J. C., \& Rodgers, T. S. (1995). Approaches and Methods in Language Teaching Cambridge University Press, Cambridge.

Scales, J. (2006). Language Learners' Perceptions of Accent. TESOL Quarterly, 40(4), 715-738. http://dx.doi.org/10.2307/40264305

Schairer, K. E. (1992). Native Speaker Reaction to Non-Native Speech. The Modern Language Journal, 76(3), 309-319. http://dx.doi.org/10.1111/j.1540-4781.1992.tb07001.x

Tergujeff, E. (2012). English Pronunciation Teaching: Four Case Studies from Finland. Journal of Language Teaching and Research, 3(4), 599-607. http://dx.doi.org/10.4304/jltr.3.4.599-607

Wahba, E. (1998). Teaching Pronunciation - Why? Language Teaching Forum, 36, 3-32.

\section{Copyrights}

Copyright for this article is retained by the author(s), with first publication rights granted to the journal.

This is an open-access article distributed under the terms and conditions of the Creative Commons Attribution license (http://creativecommons.org/licenses/by/3.0/). 